\title{
Polyploidy and Speciation in Pteris (Pteridaceae)
}

\author{
Yi-Shan Chao, ${ }^{1,2}$ Ho-Yih Liu, ${ }^{1}$ Yu-Chung Chiang, ${ }^{1}$ and Wen-Liang Chiou ${ }^{2}$ \\ ${ }^{1}$ Department of Biological Sciences, National Sun Yat-Sen University, Kaohsiung 804, Taiwan \\ ${ }^{2}$ Division of Botanical Garden, Taiwan Forestry Research Institute, Taipei 100, Taiwan
}

Correspondence should be addressed to Yu-Chung Chiang, yuchung@mail.nsysu.edu.tw and Wen-Liang Chiou, chiou@tfri.gov.tw

Received 6 June 2011; Revised 19 December 2011; Accepted 6 January 2012

Academic Editor: Kang Chong

Copyright (C) 2012 Yi-Shan Chao et al. This is an open access article distributed under the Creative Commons Attribution License, which permits unrestricted use, distribution, and reproduction in any medium, provided the original work is properly cited.

\begin{abstract}
The highest frequency of polyploidy among plants is considered to occur in the Pteridophytes. In this study, we focused on polyploidy displayed by a specific fern taxon, the genus Pteris L. (Pteridaceae), comprising over 250 species. Cytological data from 106 Pteris species were reviewed. The base number of chromosomes in Pteris is 29. Polyploids are frequently found in Pteris, including triploids, tetraploids, pentaploids, hexaploids, and octoploids. In addition, an aneuploid species, P. deltodon Bak., has been recorded. Furthermore, the relationship between polyploidy and reproductive biology is reviewed. Among these 106 Pteris species, $60 \%$ exhibit polyploidy: $22 \%$ show intraspecific polyploidy and $38 \%$ result from polyploid speciation. Apogamous species are common in Pteris. Diploids are the most frequent among Pteris species, and they can be sexual or apogamous. Triploids are apogamous; tetraploids are sexual or apogamous. Most Pteris species have one to two ploidy levels. The diverse ploidy levels suggest that these species have a complex evolutionary history and their taxonomic problems require further clarification.
\end{abstract}

\section{Introduction}

Polyploidy provides a rapid route for species evolution and adaptation $[1,2]$. Taxa arising from polyploidy are usually characterized by divers gene expression [3]. This variation in gene expression also has effects on ecological traits, which play an important role in speciation because a specialised niche is a key factor in the formation of new taxa [4-8]. For example, ecological isolation can allow taxa with genetic variation to become segregated [9]. It is estimated that the highest frequency of polyploidy is exhibited in ferns. The frequency of polyploid speciation in ferns is $31 \%$, which is much higher than $15 \%$ in angiosperms [10].

In ferns, a special form of asexual reproduction known as apogamy is common $[11,12]$. Apogamy provides a bypass to crossover mispairing of chromosomes and stabilises the reproduction of polyploids [13-15]. During metaphase I of meiosis, these polyploids present multivalents, which may have difficulty separating equally. Apogamous species are clonal hybrid genotypes, and, as a result, apogamy creates reproductive barriers that prevent gene flow among closely related taxa, thereby facilitating sympatric speciation [16]. Each taxon maintains an independent genetic lineage, leading eventually to a new species.
Pteris L. (Pteridaceae) is a cosmopolitan fern genus with over 250 species. Some Pteris species have several different ploidy levels and are found in several geographical areas, such as $P$. cretica and $P$. vittata $[11,17,18]$, which likely reflect the ecological differentiation within species. For example, different niche preferences have been found in $P$. fauriei [19]. In addition, polyploidy can also cause morphological novelty. Species complexes in Pteris have been frequently reported $[20,21]$. Those species complexes are usually composed of a group of taxa with similar morphologies and involved several polyploids. This paper depicts the cytotypes, breeding systems, character variations, and their relationships in the genus Pteris.

\section{Cytotypes of Pteris Species}

The first studies of polyploidy in Pteris focused mainly on ploidy differences and apogamy of P. cretica [22]. Walker [12] provided the first comprehensive cytological study of the genus Pteris, which included 82 species, and reported that the base number of chromosomes in Pteris is 29. In the current study, data from previous cytological studies of 106 Pteris species were integrated (Table 1). The data 
TABLe 1: Ploidy levels and breeding systems of 106 Pteris species.

\begin{tabular}{|c|c|c|c|c|c|c|c|c|c|}
\hline & $\begin{array}{c}\text { Sexual } \\
2 \mathrm{X}\end{array}$ & $\begin{array}{l}\text { Apogamous } \\
2 \mathrm{X}\end{array}$ & $2 \mathrm{X}$ & $\begin{array}{l}\text { Apogamous } \\
3 \mathrm{X}\end{array}$ & $\begin{array}{c}\text { Sexual } \\
4 \mathrm{X}\end{array}$ & $\begin{array}{l}\text { Apogamous } \\
4 \mathrm{X}\end{array}$ & $4 \mathrm{X}$ & Others & Reference \\
\hline P. acanthoneura Alston & $\mathrm{V}$ & & & & & & & & {$[12]$} \\
\hline P. actiniopteroides Christ & & & & $\mathrm{V}$ & & & & & [12] \\
\hline P. albersii Hieron. & & & & & & $\mathrm{V}$ & $\mathrm{V}$ & & {$[12,25]$} \\
\hline P. altissima Poir. & & & & & $\mathrm{V}$ & & & & [12] \\
\hline P. arguta Aiton & $\mathrm{V}$ & & & & & & & & {$[12]$} \\
\hline P. argyraea Moore & $\mathrm{V}$ & $\mathrm{V}$ & & $\mathrm{V}$ & & & & & {$[12,24]$} \\
\hline P. aspericaulis Wall. & $\mathrm{V}$ & & & $\mathrm{V}$ & & & & & {$[12,26]$} \\
\hline P. atrovirens Willd. & & & & & $\mathrm{V}$ & & & & {$[12]$} \\
\hline P. bella Tagawa & & & $\mathrm{V}$ & $\mathrm{V}$ & $\mathrm{V}$ & & & & {$[27,28]$} \\
\hline P. berteroana Ag. & $\mathrm{V}$ & & & & & & & & [27] \\
\hline P. biaurita L. & & $\mathrm{V}$ & & $\mathrm{V}$ & & & & $6 \mathrm{X}$ & {$[12,29,30]$} \\
\hline P. bifurcata Ching & & & & $\mathrm{V}$ & & & & & {$[24]$} \\
\hline P. boninensis $\mathrm{H}$. Ohba & $\mathrm{V}$ & & & & & & & & {$[31]$} \\
\hline P. buchananii Bak. ap. Sim. & $\mathrm{V}$ & & & & & & & & {$[12]$} \\
\hline P. burtonii Bak. & $\mathrm{V}$ & & & & & & & & {$[12]$} \\
\hline P. cadieri Christ & & $\mathrm{V}$ & & $\mathrm{V}$ & & & & & {$[32]$} \\
\hline P. camerooniana Kuhn & $\mathrm{V}$ & & & & & & & & {$[12,33]$} \\
\hline P. catoptera Kze. & $\mathrm{V}$ & & & & & & & & [12] \\
\hline P. comans Forst. & $\mathrm{V}$ & & & & & & & & {$[12,24]$} \\
\hline P. confusa T. G. Walker & & $\mathrm{V}$ & & & & & & & {$[12]$} \\
\hline P. cretica $\mathrm{L}$. & $\mathrm{V}$ & $\mathrm{V}$ & & $\mathrm{V}$ & & $\mathrm{V}$ & $\mathrm{V}$ & & {$[11,34-39]$} \\
\hline P. dactylina Hook. & & & & $\mathrm{V}$ & & & & & {$[12,24,38]$} \\
\hline $\begin{array}{l}\text { P. } \times \text { delchampsii W.H.Wagner \& } \\
\text { Nauman }\end{array}$ & & & & & & $\mathrm{V}$ & & & {$[40]$} \\
\hline P. deltodon Bak. & $\mathrm{V}$ & & & $\mathrm{V}$ & & & & Sexual $n=53,55$ & {$[18,23,27]$} \\
\hline P. dentata Forsskal & $\mathrm{V}$ & & & & & & & & {$[12]$} \\
\hline P. dispar Kze. & $\mathrm{V}$ & & $\mathrm{V}$ & & & & $\mathrm{V}$ & & {$[12,23,24,27]$} \\
\hline P. ensiformis Burm. & $\mathrm{V}$ & & & $\mathrm{V}$ & $\mathrm{V}$ & $\mathrm{V}$ & & $5 X ; 2 n=84,168$ & $\begin{array}{c}{[12,18,23,27} \\
41-44]\end{array}$ \\
\hline P. esquirolii Christ & & & & $\mathrm{V}$ & & & & & {$[24]$} \\
\hline P. excelsa Gaud. & $\mathrm{V}$ & $\mathrm{V}$ & & $\mathrm{V}$ & & & $\mathrm{V}$ & & {$[18,24,45]$} \\
\hline P. fauriei Hieron. & $\mathrm{V}$ & & & $\mathrm{V}$ & & & & & $\begin{array}{c}{[12,27,39,44,} \\
46]\end{array}$ \\
\hline P. formosana Bak. & $\mathrm{V}$ & & & & & & & & {$[33]$} \\
\hline P. friesii Hieron. & & & & $\mathrm{V}$ & & & & & {$[12]$} \\
\hline P. gallinopes Ching & & & & & & $\mathrm{V}$ & & & {$[18]$} \\
\hline P. gongalensis T. G. Walker & & & & $\mathrm{V}$ & & & & & {$[12]$} \\
\hline P. grandifolia $\mathrm{L}$. & & & & & $\mathrm{V}$ & & & & [12] \\
\hline P. grevilleana Wall. ex Agardh & & $\mathrm{V}$ & & & & $\mathrm{V}$ & & & {$[12,32,47]$} \\
\hline P. haenkeana Presl & & & & & & & $\mathrm{V}$ & & [12] \\
\hline P. hamulosa Christ & $\mathrm{V}$ & & & & & & & & {$[12]$} \\
\hline P. henryi Christ & $\mathrm{V}$ & & & & & & & & {$[39]$} \\
\hline P. hexagona (L.) Proctor & & & & & $\mathrm{V}$ & & & & {$[12]$} \\
\hline P. holttumii C. Chr. & & & & & $\mathrm{V}$ & & & & {$[12]$} \\
\hline P. hookeriana Ag. & & & $\mathrm{V}$ & & & & & & {$[33]$} \\
\hline P. incompleta Cav. & $\mathrm{V}$ & & & & & & & & {$[24]$} \\
\hline P. insignis Mett. ex Kuhn & & & & & $\mathrm{V}$ & & & & {$[12]$} \\
\hline P. intricata Wright & & & & & & & & $\mathrm{V}$ & {$[22]$} \\
\hline P. kidoi Kurata & $\mathrm{V}$ & & & & & & & & {$[23,48,49]$} \\
\hline
\end{tabular}


Table 1: Continued.

\begin{tabular}{|c|c|c|c|c|c|c|c|c|c|}
\hline & $\begin{array}{c}\text { Sexual } \\
2 \mathrm{X}\end{array}$ & $\begin{array}{c}\text { Apogamous } \\
2 \mathrm{X}\end{array}$ & $2 \mathrm{X}$ & $\begin{array}{c}\text { Apogamous } \\
3 \mathrm{X}\end{array}$ & $\begin{array}{c}\text { Sexual } \\
4 \mathrm{X}\end{array}$ & $\begin{array}{c}\text { Apogamous } \\
4 \mathrm{X} \\
\end{array}$ & $4 \mathrm{X}$ & Others & Reference \\
\hline P. kingiana Endl. & & & & $\mathrm{V}$ & & & & & [24] \\
\hline P. kiuschiuensis Hieron. & & V & & $\mathrm{V}$ & & & & & {$[21,50,51]$} \\
\hline P. laurisilvicola Kurata & & V & & $\mathrm{V}$ & & & & & {$[24]$} \\
\hline P. ligulata Gaud. & & & & & $\mathrm{V}$ & & & & {$[12]$} \\
\hline P. linearis Poir. & & V & & $\mathrm{V}$ & $\mathrm{V}$ & & & & {$[27,28]$} \\
\hline P. lineata Poir. et Lam. & & $\mathrm{V}$ & & & & & & & [39] \\
\hline P. longifolia L. & V & & & & $\mathrm{V}$ & & & & {$[12,24]$} \\
\hline P. longipes D. Don & & & & & & & V & & {$[24]$} \\
\hline P. longipinnula Wall. & & & & & & & V & & {$[24]$} \\
\hline P. macilenta A. Rich. & & & & & $\mathrm{V}$ & & & & {$[12]$} \\
\hline P. marginata Bory & V & & & & & & & & {$[12]$} \\
\hline P. multiaurita Ag. & V & & & & & & & & {$[12]$} \\
\hline P. multifida Poir. & & & & & $\mathrm{V}$ & & V & & $\begin{array}{c}{[12,18,23,27,} \\
45,52]\end{array}$ \\
\hline P. nakasimae Tagawa & & & & & V & & & & {$[12,23]$} \\
\hline P. $\times$ namegatae Kurata & & & & & & & $\mathrm{V}$ & & {$[23]$} \\
\hline P. natiensis Tagawa & & V & & & & & & & {$[51]$} \\
\hline P. nemoralis Willd. & $\mathrm{V}$ & & & & & & & & [24] \\
\hline P. nipponica Shieh & & & & V & & & & & {$[33,53]$} \\
\hline P. orientalis Alderw. & & & & & & & & & {$[54]$} \\
\hline P. oshimensis Hieron. & & V & & $\mathrm{V}$ & & & & & {$[18,50,55]$} \\
\hline P. otaria Bedd. & V & & & & & & & & {$[12,29]$} \\
\hline P. pacifica Hieron. & & & $\mathrm{V}$ & $\mathrm{V}$ & & & & & {$[12,24]$} \\
\hline P. palustris Poir. & V & & & & & & & & {$[24]$} \\
\hline P. papuana Ces. & & & & & $\mathrm{V}$ & & & & {$[12]$} \\
\hline P. pellucida Presl & V & & & & $\mathrm{V}$ & & $\mathrm{V}$ & & {$[12,31]$} \\
\hline P. pellucidifolia Hayata & & & & $\mathrm{V}$ & & & & & {$[36]$} \\
\hline P.plumula Desv. & & & & & & $\mathrm{V}$ & & & {$[12]$} \\
\hline P. podophylla Sw. & & & $\mathrm{V}$ & & & & & & {$[24]$} \\
\hline P. praetermissa T. G. Walker & $\mathrm{V}$ & & & & & & & & {$[12]$} \\
\hline P. pseudoquadriaurita Khullar & V & & & & & & & & {$[24]$} \\
\hline P. quadriaurita Retz. & $\mathrm{V}$ & & & $\mathrm{V}$ & & $\mathrm{V}$ & & & {$[12,20]$} \\
\hline P. reptans T.G. Walker & V & & & & & & & & {$[12]$} \\
\hline P. roseo-lilacina Hieron. & V & & & & & & & & {$[12]$} \\
\hline P. ryukyuensis Tagawa & & & & & $\mathrm{V}$ & & & & {$[55,56]$} \\
\hline P. saxatilis Carse & V & & & & & & & & {$[12]$} \\
\hline P. scabripes Wall. & $\mathrm{V}$ & $\mathrm{V}$ & & & & & & & {$[12,24]$} \\
\hline P. scabristipes Tagawa & & & & $\mathrm{V}$ & & & & & {$[24]$} \\
\hline P. $\times$ sefuricola Sa. Kurata & & & & & & $\mathrm{V}$ & & & {$[34]$} \\
\hline P. semipinnata L. & & & & $\mathrm{V}$ & $\mathrm{V}$ & & & & {$[12,23,27]$} \\
\hline P. setuloso-costulata Hayata & & & $\mathrm{V}$ & V & & & & & {$[23,27,53]$} \\
\hline P. silentvalliensis $\mathrm{N}$. C. Nair & & & & $\mathrm{V}$ & & & & & {$[24]$} \\
\hline P. similis Kuhn & & & $\mathrm{V}$ & & & & & & {$[12]$} \\
\hline P. spinescens $\mathrm{C}$. Presl & & & $\mathrm{V}$ & & & & & & {$[24,57]$} \\
\hline P. stenophylla Wall. ex Hook. \& Grev. & $\mathrm{V}$ & & & & & & & & {$[12]$} \\
\hline P. subquinata (Wall. ex Bedd.) Agardh & $\mathrm{V}$ & & & & & & & & {$[24]$} \\
\hline P. togoensis Hieron. & $\mathrm{V}$ & & & & & & & & {$[12]$} \\
\hline
\end{tabular}


Table 1: Continued.

\begin{tabular}{|c|c|c|c|c|c|c|c|c|c|}
\hline & $\begin{array}{l}\text { Sexual } \\
2 \mathrm{X}\end{array}$ & $\begin{array}{c}\text { Apogamous } \\
2 \mathrm{X}\end{array}$ & $2 \mathrm{X}$ & $\begin{array}{c}\text { Apogamous } \\
3 \mathrm{X} \\
\end{array}$ & $\begin{array}{c}\text { Sexual } \\
4 \mathrm{X} \\
\end{array}$ & $\begin{array}{c}\text { Apogamous } \\
4 \mathrm{X}\end{array}$ & $4 \mathrm{X}$ & Others & Reference \\
\hline P. tokioi Masam. & & & & & $\mathrm{V}$ & & $\mathrm{V}$ & & {$[27,50,55]$} \\
\hline P. trachyphylla Kunze. & & $\mathrm{V}$ & & & & & & & [12] \\
\hline P. tremula R. Br. & & & & & & & & Sexual $8 \mathrm{X}$ & {$[12]$} \\
\hline P. tripartita Sw. & $\mathrm{V}$ & & & & $\mathrm{V}$ & & & & {$[12,35]$} \\
\hline P. umbrosa R. Br. & & & & & $\mathrm{V}$ & & & & {$[12]$} \\
\hline P. vellucida* & & & $\mathrm{V}$ & & & & & & {$[24]$} \\
\hline P. vittata $\mathrm{L}$. & $\mathrm{V}$ & & & $\mathrm{V}$ & $\mathrm{V}$ & $\mathrm{V}$ & & $5 X, 6 X$ & $\begin{array}{c}{[1,12,17,18,27,} \\
35,39,44,58]\end{array}$ \\
\hline P. wallichiana Agardh & $\mathrm{V}$ & & & & & & & & {$[12,18,27,44]$} \\
\hline P. wangiana Ching & & & & $\mathrm{V}$ & & & & & {$[24]$} \\
\hline P. warburgii Christ & & & $\mathrm{V}$ & & & & & & {$[54]$} \\
\hline P. werneri (Rosenstock) Holtt. & & & $\mathrm{V}$ & & & & & & {$[25]$} \\
\hline P. wulaiensis C.M.Kuo & & $\mathrm{V}$ & & & & & & & {$[36]$} \\
\hline P. xiaoyingae $\mathrm{H} . \mathrm{He} \&$ L. B. Zhang & & $\mathrm{V}$ & & & & & & & [59] \\
\hline P. yamatensis (Tagawa) Tagawa & & & & & $\mathrm{V}$ & & & & {$[12,23]$} \\
\hline
\end{tabular}

?means unknown.

* It is accorded to the literature. $P$. vellucida could be misspelling of $P$. pellucida.

of some varieties were combined into species. The degree of polyploidy varies in Pteris, including triploid, tetraploid, pentaploid, hexaploid, and octoploid species. In addition, an aneuploid species, $P$. deltodon Bak., with 53, 55, and 82 chromosomes per gamete has been reported [18, 23, 24].

Among the 106 Pteris species examined, 43 (40\%) are diploid, the most common cytotype in this genus (Figure 1). Among the remaining 40 polyploid species (38\%), there are 13 triploids, 26 tetraploids, and 1 octoploid. Octoploidy in $P$. tremula R. Br. is the highest ploidy level recorded. Compared to the $34 \%$ level of polyploidy in all leptosporangiate ferns [10], polyploid speciation is apparently much more common in the genus Pteris. The highest ploidy levels found in all fern genera, such as dodecaploids and hexadecaploids in Asplenium [12], were not found in the genus Pteris.

Of the 106 species of Pteris examined, most of the individuals in a species have only one ploidy level. In contrast, intraspecific polyploids are found in the other 23 species, $22 \%$ of genus Pteris. Nine species include both diploid and triploid individuals, and four species include both diploids and tetraploids plants. No species comprised solely triploids or tetraploids. Six species have individuals with three ploidy levels, diploids, triploids, and tetraploids (Figure 1). Four species with other intraspecific ploidy combinations were grouped in the "others" in Figure 1. Specifically, Pteris biaurita L. and P. ensiformis Burm. include individuals having four ploidy levels, that is, diploids, triploids, tetraploids, and hexaploids. Also, Pteris vittata L. exhibits pentaploidy in addition to the above four ploidy levels. Finally, Pteris deltodon is aneuploid species. Some of the triploids and tetraploids in the genus clearly arose from autopolyploidy. For example, 29 trivalent chromosomes were found in the triploid P. fauriei Hieron (P. fauriei var. fauriei) [27], and 29 tetravalent chromosomes were found in Pteris

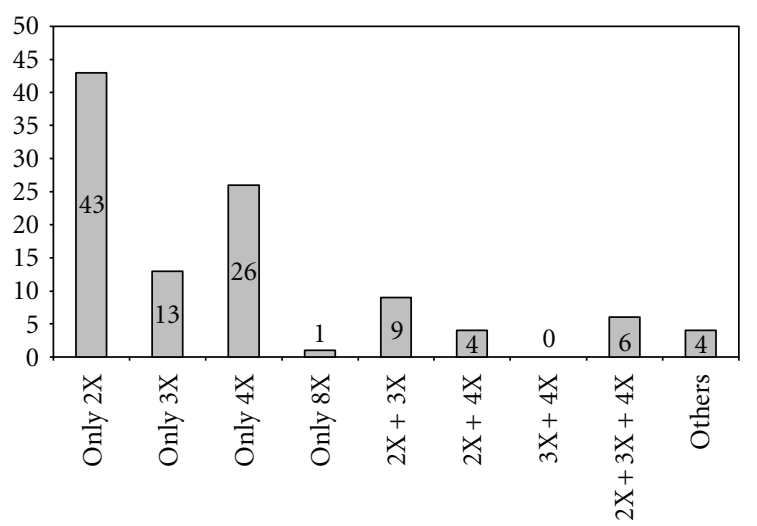

Figure 1: The cytotypes of the 106 Pteris species in this review.

tokioi Masam [27]. Overall, the frequency of the above intraspecific variation in ploidy level in Pteris is lower than the $33 \%$ reported for all leptosporangiate ferns [10].

\section{Polyploids and Breeding Systems}

The most common breeding system in the genus Pteris is sexual (48 species) (Figure 2), followed by apogamous (33 species), then species with both sexual and apogamous reproduction (13 species). Sexual reproduction is more frequent than apogamous in both diploids $(28 \%>11 \%)$ and tetraploids $(15 \%>7 \%)$ (Figure 3 ). Some other cytotypes could be sexual. For example, $P$. tremula is a sexual octoploid. Although P. deltodon is aneuploid, sexual diploids $(n=53,55)$ are also found in this species [18].

Apogamy is found in 39\% of all cytotypes and $28 \%$ of polyploids (Figure 3; diploids 11\%, triploids 21\%, 


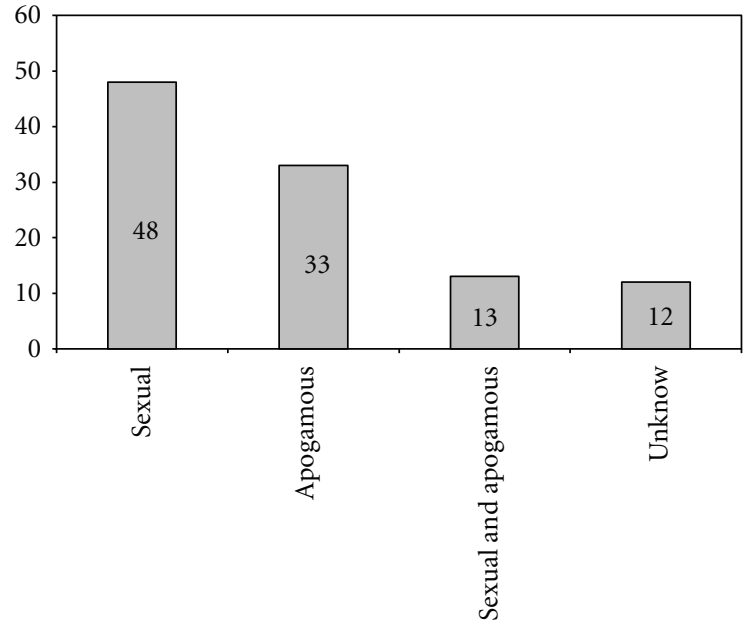

Figure 2: The breeding systems of the 106 Pteris species in this review.

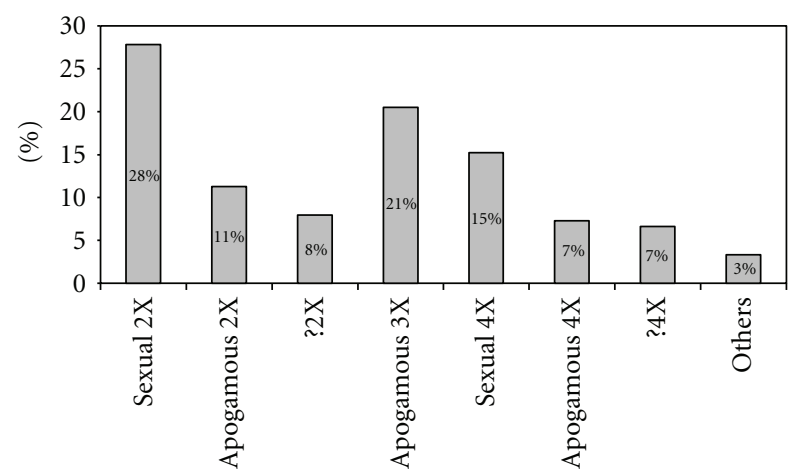

Figure 3: The breeding systems and cytotypes of the 106 Pteris species in this paper.

tetraploids 7\%). Apogamous diploids are considered to originate from the hybridisation of two sexual diploid species followed by acquired apogamy or from genetic change of a sexual diploid species [11]. Apogamous triploids could derive from a cross between sexual diploid and tetraploid species or between apogamous diploids (unreduced, diploid gametes, functionally male) and sexual diploids $[5,11-14$, 48,60 ]. Diploids appear to be the ancestors of the triploids; however, ploidy reduction is also possible: triploids produced the diploid apogamous Dryopteris pacifica. Such diploids may be derived from partial synapsis and segregation [61].

All triploids were found to be apogamous. In both autotriploids and allotriploids, disordered chromosome separation occurs; trivalents in autotriploids and a bivalent plus a univalent in allotriploids cannot be resolved into balanced products. Without apogamous reproduction, spores from autotriploids do not have balanced chromosome complements and, thus, are not viable $[62,63]$.

The number of sexual tetraploids is greater than that of apogamous ones. Tetraploids could arise via chromosome doubling in a diploid and maintain sexual reproduction thereafter. Tetraploids can also arise from another mechanism, the so-called "triploid bridge" [2]. In this case, a triploid arises from the fusion of a reduced (haploid) and an unreduced (diploid) gamete. Furthermore, crossing of the unreduced gametes of that apogamous triploid with the haploid gametes of a sexual diploid could produce apogamous tetraploids [64].

\section{Polyploidy and the Variation of Pteris Species}

The variation among infraspecific polyploids may reveal the contribution of polyploidy to speciation. Such variation could include differences in morphology, ecology, cytology, and reproduction. These variations might not be easily distinguished in infraspecific polyploids, which are usually referred to as a "species complex." Furthermore, possible cryptic species could lurk inside. Below are some examples of these phenomena in Pteris species.

Pteris fauriei includes sexual diploids and apogamous triploids, $P$. fauriei var. minor and P. fauriei var. fauriei, respectively [46]. Because the triploids have 29 trivalents at meiosis [27], it is likely that they arose via autopolyploidy. Diploids of this species often grow in exposed sites and grasslands and prefer warmer habitats than the triploids [19]. Although only genome dosage distinguishes the diploid and triploid taxa, polyploidy caused ecological differentiation between the taxa.

Pteris cretica is widely distributed in warm-temperate and tropical parts of the Old World [65]. It could be one of the most attractive materials in Pteris studies. Early studies revealed apogamy and different ploidy levels in the species [11], while subsequent studies reported variable morphology and ploidy levels, including diploids, triploids, and tetraploids [12, 34-36] (Table 1). Although the sexual diploid P. cretica has been reported, apogamous diploids, triploids, and tetraploids of this species suggest possible hybridisation events. The presence of a bivalent plus a univalent during meiosis provides distinct evidence of such hybridization $[37,66]$. Based on allozyme banding patterns, the triploid P. cretica may derive from the diploid apogamous $P$. cretica and the diploid sexual P. kidoi [48]. Furthermore, an apogamous intermediate form between the sexual tetraploid P. multifida and the apogamous diploid P. cretica has been reported [34].

Pteris ensiformis occurs in India, Sri Lanka, SE Asia, and Polynesia, although now it is also widely naturalised elsewhere in the tropics [65]. Its cytotypes include diploid, triploid, tetraploid, and pentaploid. The triploid may have arisen from a cross between sexual diploids and sexual tetraploids. The origin of the pentaploid is more complicated to infer; however, hybridisation is suggested by the failure of chromosome pairing at meiosis [41]. Pteris ensiformis var. victoriae $\mathrm{Ba}$. was reported to be aneuploid $(2 n=84,168)$ [42]. Given the various morphologies of P. ensiformis, this species likely underwent multiple hybridisations and possibly contains cryptic species.

Pteris quadriaurita is a well-known species complex that includes $P$. quadriaurita sensu stricto, $P$. multiaurita, $P$. confusa, and $P$. otaria $[20,21]$. Their radically different morphologies make these taxa difficult to identify. Field 
hybridisation experiments have provided evidence that this species complex arose from recurrent hybridisation events, that is, a hybrid swarm. The fact of both sexual and apogamous reproductive systems and divers ploidy levels, including diploid, triploid, and tetraploid, indicates the undergoing speciation of this complex.

Pteris deltodon has diploids and triploids. Furthermore, its aneuploid cytotypes, $n=53$ and 55 , indicate that it is also hypotetraploid (Table 1 ). The appearance of aneuploids is limited, with only two records in China and Japan $[18,23]$. The species likely arose from allopolyploidy, but it is now a "stable" species because of its sexual reproduction and 64 spores per sporangium [18].

The Chinese ladder brake $P$. vittata shows considerable morphological variations and wide geographical distribution throughout the world. Diverse ploidy levels and reproductive modes have been recorded, including sexual diploids, triploids, sexual and apogamous tetraploids, pentaploids, and hexaploids (Table 1). Furthermore, the spore mother cells show a variety of multivalents, such as $20 \mathrm{I}+26 \mathrm{II}+$ 5III, 9I + 45II + 3III + 2IV, 29II + 29I, and 29II + 87I $[17,18]$, indicating the occurrence of allopolyploidy. The species involved are not clear, and further taxonomical study on this species complex is needed.

\section{Conclusion}

We reviewed the cytological data of 106 Pteris species, and $60 \%$ of them exhibit polyploidy, with a frequency of polyploid speciation $38 \%$. This ratio, however, could be underestimated. Since the taxonomy of Pteris remains unclear, some cryptic species may exist in the $22 \%$ species with intraspecific polyploidy. Integration of further cytological data with reproductive and morphological studies should clarify Pteris systematics including species delimitations and also the evolutionary history of its taxa.

\section{Authors' contribution}

Y. S. Chao and H. Y. Liu contributed equally to this work.

\section{Acknowledgments}

The authors thank Dr. Craig Martin for English editorial assistance and anonymous reviewer for valuable comments. This study was supported by grants from Taiwan Forestry Research Institute (96AS-11.1.2-FI-G1, 97AS-11.2.2-EI-W4, and 98AS-8.2.1-F1-G1) awarded to W.-L. Chiou, and the National Science Council of Taiwan awarded to Y.-C. Chiang.

\section{References}

[1] V. Grant, Plant Speciation, Columbia University Press, New York, NY, USA, 1981.

[2] L. H. Rieseberg and J. H. Willis, "Plant speciation," Science, vol. 317, no. 5840, pp. 910-914, 2007.

[3] P. S. Soltis and D. E. Soltis, "The role of genetic and genomic attributes in the success of polyploids," Proceedings of the
National Academy of Sciences of the United States of America, vol. 97, no. 13, pp. 7051-7057, 2000.

[4] C. N. Page, "Ecological strategies in fern evolution: a neopteridological overview," Review of Palaeobotany and Palynology, vol. 119, no. 1-2, pp. 1-33, 2002.

[5] C. H. Haufler, M. D. Windham, D. M. Britton, and S. J. Robinson, "Triploidy and its evolutionary significance in Cystopteris protrusa," Canadian Journal of Botany, vol. 63, no. 10, pp. 1855-1863, 1985.

[6] J. Ramsey and D. W. Schemske, "Neopolyploidy in flowering plants," Annual Review of Ecology and Systematics, vol. 33, pp. 589-639, 2002.

[7] D. M. Rosenthal, A. E. Schwarzbach, L. A. Donovan, O. Raymond, and L. H. Rieseberg, "Phenotypic differentiation between three ancient hybrid taxa and their parental species," International Journal of Plant Sciences, vol. 163, no. 3, pp. 387398, 2002.

[8] B. L. Gross and L. H. Rieseberg, "The ecological genetics of homoploid hybrid speciation," Journal of Heredity, vol. 96, no. 3, pp. 241-252, 2005.

[9] J. C. Vogel, F. J. Rumsey, S. J. Russell et al., "Genetic structure, reproductive biology and ecology of isolated populations of Asplenium csikii (Aspleniaceae, Pteridophyta)," Heredity, vol. 83, no. 5, pp. 604-612, 1999.

[10] T. E. Wood, N. Takebayashi, M. S. Barker, I. Mayrose, P. B. Greenspoon, and L. H. Rieseberg, "The frequency of polyploid speciation in vascular plants," Proceedings of the National Academy of Sciences of the United States of America, vol. 106, no. 33, pp. 13875-13879, 2009.

[11] I. Manton, Problems of Cytology and Evolution in the Pteridophyta, Columbia University Press, New York, NY, USA, 1950.

[12] T. G. Walker, "Cytology and evolution in the fern genus Pteris L.," Evolution, vol. 16, no. 1, pp. 17-43, 1962.

[13] J. D. Lovis, "Evolutionary patterns and processes in ferns," Advances in Botanical Research, vol. 4, no. C, pp. 229-415, 1978.

[14] T. G. Walker, The Experimental Biology of Ferns, Academic Press, Londo, UK, 1979, Edited by A. F. Dyer.

[15] L. G. Hickok and E. J. Klekowski Jr., "Inchoate speciation in Ceratopteris:an analysis od the synthesized hybrid C. richardii $x$ C. pteridoides," Evolution, vol. 28, pp. 439-446, 1974.

[16] C. R. Werth and M. D. Windham, "A model for divergent, allopatric speciation of polyploid pteridophytes resulting from silencing of duplicate-gene expression," The American Naturalist, vol. 137, no. 4, pp. 515-526, 1991.

[17] P. Khare and S. Kaur, "Intraspecific polyploidy in Pteris vittata Linn.”, Cytologia, vol. 48, no. 1, pp. 21-25, 1983 (Japanese).

[18] Z. R. Wang, "A preliminary study on cytology of Chinese Pteris," Acta Phytotaxonomica Sinica, vol. 27, no. 6, pp. 421438, 1989.

[19] Y.-M. Huang, H.-M. Chou, J.-C. Wang, and W.-L. Chiou, "The distribution and habitats of the Pteris fauriei complex in Taiwan," Taiwania, vol. 52, no. 1, pp. 49-58, 2007.

[20] T. G. Walker, "The Pteris quadriaurita complex in Ceylon," Kew Bulletin, vol. 14, no. 3, pp. 321-332, 1954.

[21] T. G. Walker, "Hybridization in some species of Pteris L.," Evolution, vol. 12, no. 1, pp. 82-92, 1958.

[22] I. Manton, "Chromosomes and fern phylogeny with special reference to "Pteridaceae"' Journal of the Linnean Society of London, vol. 56, no. 365, pp. 73-92, 1958.

[23] K. Iwatsuki, lora of Japan-Pteridophyta and Gymnospermae, Kodansha, Tokyo, Japan, 1995, Edited by K. Iwatsuki, T. Yamazaki, D. E. Boufford and H. Ohba. 
[24] Index to Plant Chromosome Numbers (IPCN), Missouri Botanical Garden, St. Louis, Mo, USA, 1979, Edited by P. Goldblatt and D. E. Johnson, http://www.tropicos.org/Project/IPCN/.

[25] T. G. Walker, "Additional cytogenetic notes on the pteridophytes of Jamaica," Transactions of the Royal Society of Edinburgh, vol. 69, pp. 109-135, 1973.

[26] L. S. Ammal and K. V. Bhavanandan, "Cytological studies on some members of Pteridaceae (sensu Copeland) from south India," Indian Fern Journal, vol. 8, no. 1-2, pp. 87-92, 1991.

[27] J.-L. Tsai and W.-C. Shieh, "A cytotaxonomic survey of the pteridophytes in Taiwan (2) chromosome and spore characteristics," Journal of Science \& Engineering, vol. 21, pp. 57-70, 1984.

[28] Y. J. Chang, W. C. Shieh, and J. L. Tsai, "Studies on the karyotypes of the fern genus Pteris in Taiwan," in Proceedings of the 2nd Seminar on Asian Pteridology, Taipei, Taiwan, 1992.

[29] I. Manton and W. A. Sledge, "Observations on the cytology and taxonomy of the Pteridophyte flora of Ceylon," Philosophical Transactions of the Royal Society B, vol. 238, pp. 127-185, 1954.

[30] S. K. Roy and J. B. Singh, "A note on the chromosome numbers in some ferns from Pachmarhi Hills," Central India, vol. 41, pp. $181-183,1975$.

[31] P. N. Mehra, "Chromosome number in Himalayan ferns," Research Bulletin (n.s.) of Panjab University, vol. 12, pp. 139169, 1961.

[32] Y. S. Chao, H. Y. Liu, Y. M. Huang, and W. L. Chiou, "Reproductive traits of Pteris cadieri and P. grevilleana in Taiwan: implications for their hybrid origin," Botanical Studies, vol. 51, no. 2, pp. 209-216, 2010.

[33] Á. Löve, D. Löve, and R. E. G. Sermolli, Cytotaxonomical Atlas of the Pteridophyta, Vaduz, Liechtenstein, 1977, Edited by J. Cramer.

[34] N. Nakatô, "A cytological study on an intermediate form between Pteris multifida and P. cretica," Journal of Japanese Botany, vol. 50, no. 4, pp. 110-125, 1975.

[35] R. P. Roy, B. M. B. Sinha, and A. R. Sakya, "Cytology of some ferns of Kathmandu valley,” Fern Gazette, vol. 10, pp. 193-199, 1971.

[36] Y.-M. Huang, S.-Y. Hsu, T.-H. Hsieh, H.-M. Chou, and W.L. Chiou, "Three Pteris species (Pteridaceae: Pteridophyta) reproduce by apogamy," Botanical Studies, vol. 52, p. 79, 2011.

[37] S. C. Verma and S. P. Khullar, "Cytogenetics of the Western Himalayan Pteris cretica complex," Annals of Botany, vol. 29, no. 4, pp. 673-681, 1965.

[38] S.-J. Lin, K. Iwatsuki, and M. Kato, "Cytotaxonomic study of ferns from China I. Species of Yunnan," Journal of Japanese Botany, vol. 71, no. 4, pp. 214-222, 1996.

[39] M. Kato, N. Nakato, X. Cheng, and K. Iwatsuki, "Cytotaxonomic study of ferns of Yunnan, southwestern China," The Botanical Magazine Tokyo, vol. 105, no. 1, pp. 105-124, 1992.

[40] W. H. J. Wagner and C. E. Nauman, "Pteris Xdelchampsii, a spontaneous fern hybrid from southern Florida," American Fern Journal, vol. 72, pp. 97-102, 1982.

[41] A. Abraham, "Studies on the cytology and phylogeny of the Pteridophytes VII. Observation on one hundred species of South Indian ferns," Journal of the Indian Botanical Society, vol. 41, pp. 344-348, 1962.

[42] P. I. Kuriachan and C. A. Ninan, Aspects of Plant Sciences, Today \& Tomorrow's Printers, New Delhi, India, 1976, Edited by P. K. K. Nair.

[43] W.-L. Chiou, "The gametophytes of Pteris ensiformis Burm," in Proceedings of the Seminar of Asian Pteridology II, Taipei, Taiwan, 1992.
[44] K. Mitui, "Chromosome numbers of some ferns in the Ryukyu Islands," Journal of Japanese Botany, vol. 51, pp. 33-41, 1976.

[45] N. Nakatô, "A cytogeographic study on the Japanese Pteris excelsa complex," Journal of Japanese Botany, vol. 51, pp. 5964, 1976

[46] Y. M. Huang, H. M. Chou, T. H. Hsieh, J. C. Wang, and W. L. Chiou, "Cryptic characteristics distinguish diploid and triploid varieties of Pteris fauriei (Pteridaceae)," Canadian Journal of Botany, vol. 84, no. 2, pp. 261-268, 2006.

[47] N. Nakato, "Notes on chromosomes of Japanese pteridophytes," Journal of Japanese Botany, vol. 65, pp. 204-209, 1990.

[48] T. Suzuki and K. Iwatsuki, "Genetic variation in apogamous fern Pteris cretica L. in Japan," Heredity, vol. 65, pp. 221-227, 1990.

[49] N. Nakato, "Notes on chromosomes of Japanese pteridophytes," Journal of Japanese Botany, vol. 63, pp. 214-218, 1988.

[50] K. Mitui, "Chromosomes and speciation in ferns," Science Reports of the Tokyo Kyoiku Daigaku B, vol. 13, pp. 185-333, 1968.

[51] S. Kurita, "Chromosome number of some Japanese ferns III," Journal of the College of Arts and Sciences, Chiba University, Natural Science Series, vol. 8, pp. 463-468, 1962.

[52] S. M. Kawakami, M. Ito, and S. Kawakami, "Apogamous sporophyte formation in a fern Pteris multifida and its characteristics," Journal of Plant Research, vol. 108, no. 2, pp. 181-184, 1995.

[53] K. Mitui, "Chromosome studies on Japanese ferns," Journal of Japanese Botany, vol. 41, pp. 61-64, 1966.

[54] R. E. Holttum and S. K. Roy, "Cytological observations on ferns from New Guinea with descriptions of new species," Blumea, vol. 13, pp. 129-139, 1965.

[55] K. Mitui, "Chromosome studies on Japanese ferns," Journal of Japanese Botany, vol. 42, pp. 105-110, 1967.

[56] T. Nakaike, New Flora of Japan Pteridophyta, Shibundo Company, Tokyo, Japan, 1992.

[57] N. Nakato and M. Kato, "Chromosome numbers of ten species of ferns from Guam, S. Mariana Isls.," Acta Phytotaxonomica et Geobotanica, vol. 52, pp. 125-133, 2001.

[58] J. Srivastava, S. A. Ranade, and P. B. Khare, "Distribution and threat status of the cytotypes of Pteris vittata L. (Pteridaceae) species complex in India," Current Science, vol. 93, no. 1, pp. 81-85, 2007.

[59] H. He and L. B. Zhang, "Pteris xiaoyingae, sp. nov. (sect. Pteris) from a karst cave in China based on morphological and palynological evidence," Systematic Botany, vol. 35, no. 4, pp. 695-700, 2010.

[60] S.-J. Lin, M. Kato, and K. Iwatsuki, "Electrophoretic variation of the apogamous Dryopteris varia group (Dryopteridaceae)," Journal of Plant Research, vol. 108, no. 4, pp. 451-456, 1995.

[61] S.-J. Lin, M. Kato, and K. Iwatsuki, "Diploid and triploid offspring of triploid agamosporous fern Dryopteris pacifica," The Botanical Magazine Tokyo, vol. 105, no. 3, pp. 443-452, 1992.

[62] L. Comai, "The advantages and disadvantages of being polyploid," Nature Reviews Genetics, vol. 6, no. 11, pp. 836846, 2005.

[63] R. J. Singh, Plant Cytogenetics, 2003.

[64] Y. Watano and K. Iwatsuki, "Genetic variation in the "Japanese apogamous form" of the fern Asplenium unilaterale Lam," The Botanical Magazine Tokyo, vol. 101, no. 3, pp. 213-222, 1988.

[65] K. U. Kramer and P. M. McCarthy, Flora of Australia: Ferns, Gymnosperms and Allied Genera, Collingwood, 1998.

[66] J. Jha and B. M. Sinha, "Cytomorphological variability in apogamous populations of Pteris cretica L.," Caryologia, vol. 40, pp. 71-78, 1987. 

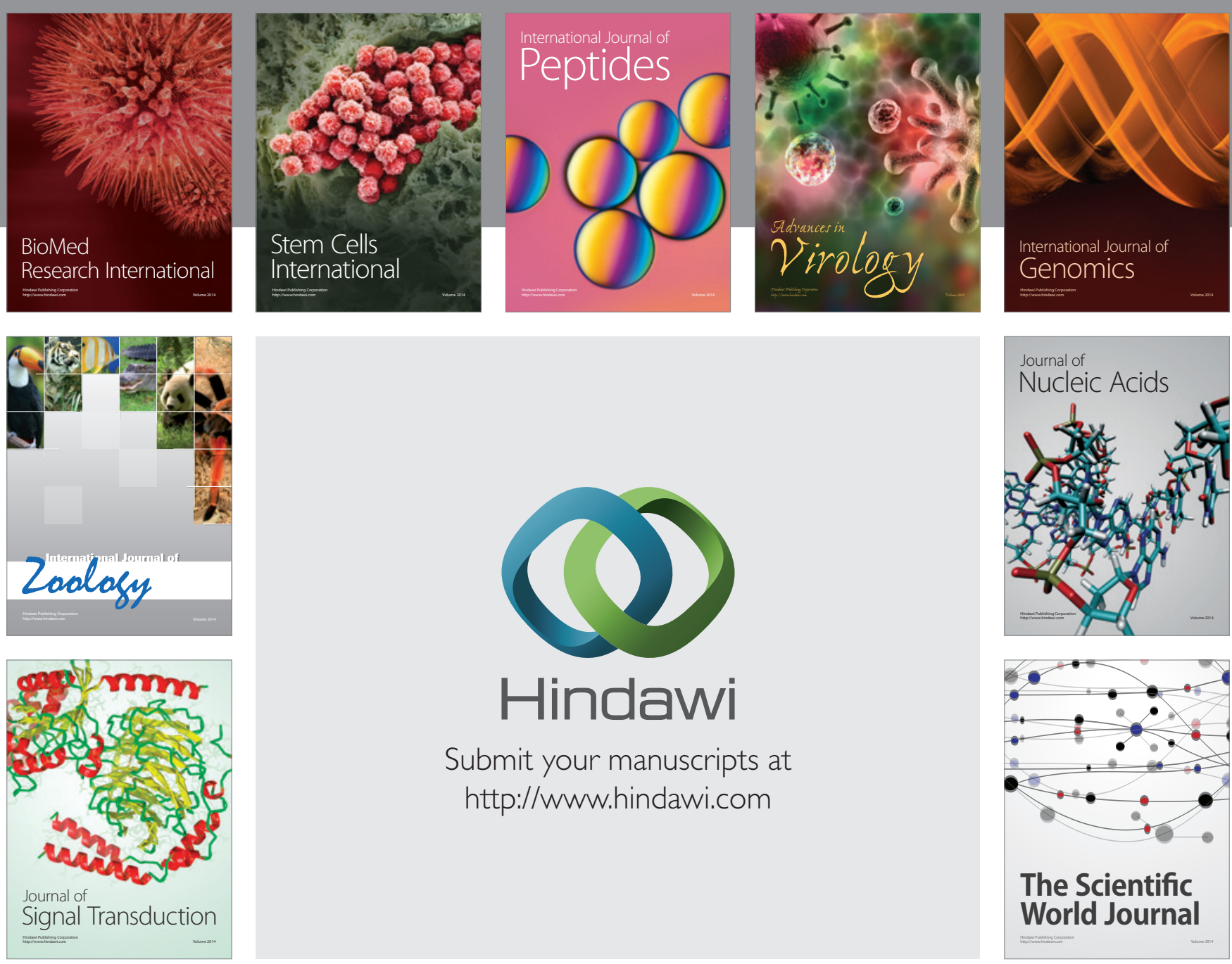

Submit your manuscripts at

http://www.hindawi.com
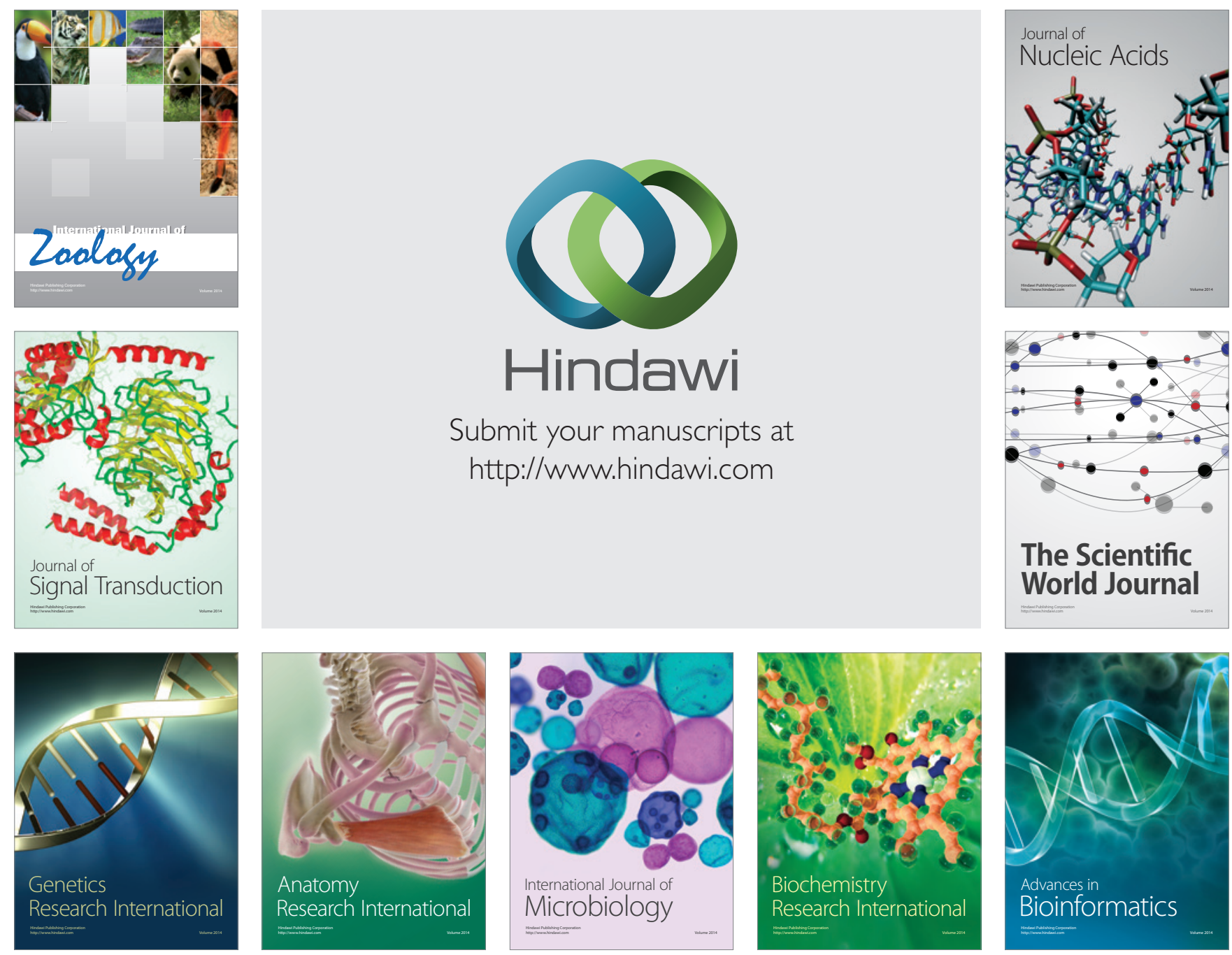

The Scientific World Journal
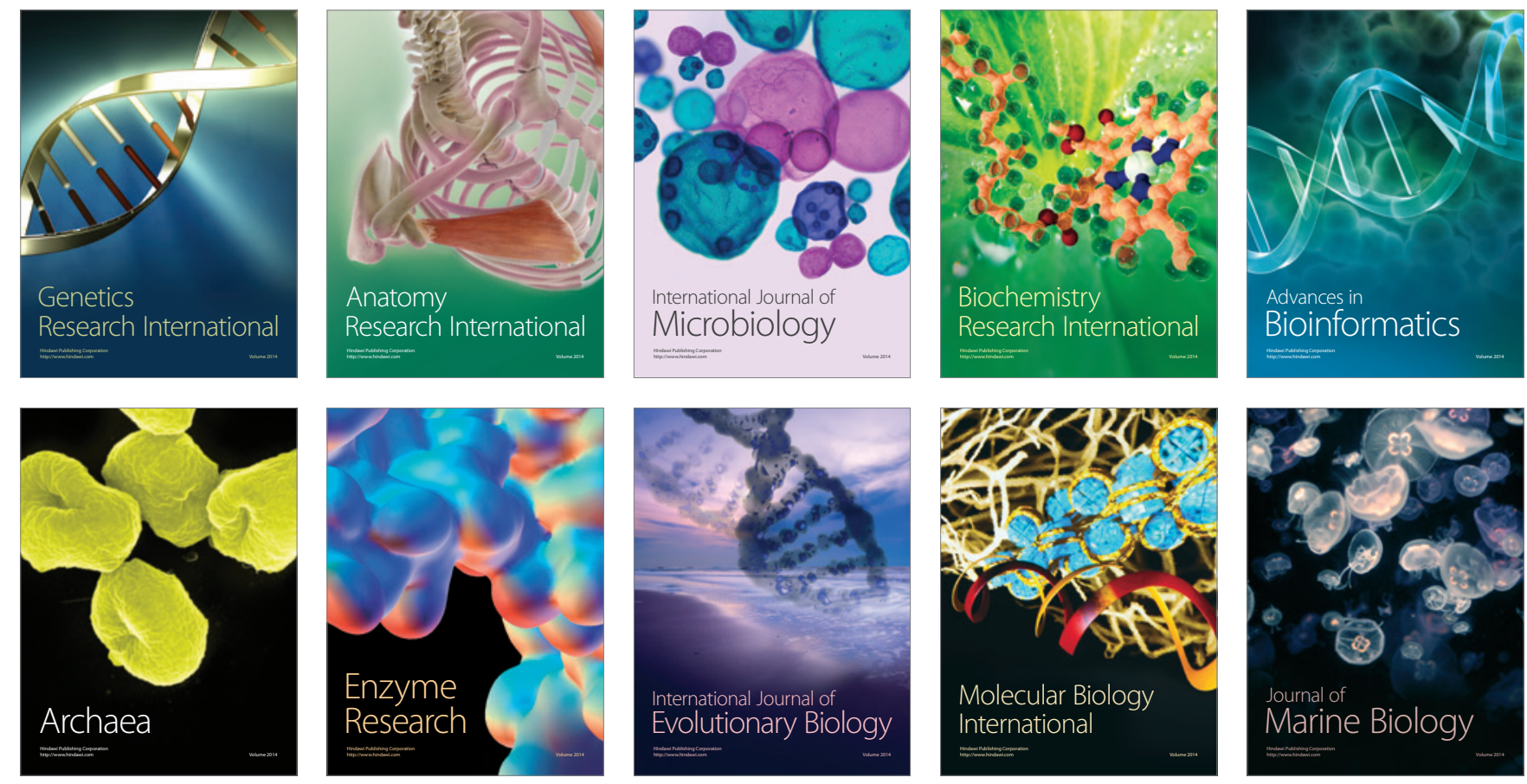